\title{
Membrane Depolarization Induces Calcium-Dependent Secretion of Tissue Plasminogen Activator
}

\author{
Anna Gualandris, ${ }^{1}$ Thomas E. Jones, ${ }^{1}$ Sidney Strickland, ${ }^{1,2}$ and Stella E. Tsirka ${ }^{1}$ \\ 1 Department of Pharmacology, and ${ }^{2}$ Program in Genetics, University Medical Center at Stony Brook, Stony Brook, \\ New York 11794-8651
}

Tissue plasminogen activator (tPA), a serine protease that converts inactive plasminogen to active plasmin, is produced in the rat and mouse hippocampus and participates in neuronal plasticity. To help define the role of IPA in the nervous system, we have analyzed the regulation of its expression in the neuronal cell line PC12. In control cultures, tPA aclivity is exclusively cell-associated, and no activity is measurable in the culture medium. When the cells are treated with depolarizing agents, such as $\mathrm{KCl}$, tPA activity becomes detectable in the medium. The increased secreted tPA activity is not accompanied by an increase in IPA mRNA levels, and it is not blocked by protein synthesis inhibitors. In contrast, tPA release is abolished by $\mathrm{Ca}^{2+}$ channel blockers, suggesting that chemically induced membrane depolarization stimulates the secretion of preformed enzyme. Moreover, $\mathrm{KCl}$ has a similar effect in vivo when administered to the murine brain via an osmotic pump: tPA activity increases along the CA2-CA3 regions and dentate gyrus of the hippocampal formation. These results demonstrate a neuronal activity-dependent secretory mechanism that can rapidly increase the amount of tPA in neuronal tissue.

Key words: PC12 cells; tPA; secretion; depolarization; calcium blockers; hippocampus
Tissue plasminogen activator (tPA), a serine protease that can convert inactive plasminogen to plasmin, is expressed in a wide range of tissues, including brain, maturing oocytes, oviduct, and endocrine pancreas (Rickles and Strickland, 1988). In some of these cases, the nature of the expression suggests that tPA has functions other than its classical fibrinolytic role. In the adult murine brain, tPA mRNA and protein activity are present in the hippocampus (Sappino et al., 1993). In both rat and mouse, this hippocampal expression is increased by events that involve neu ronal plasticity such as seizures and kindling (Qian et al., 1993; Carroll et al., 1994). Moreover, tPA-deficient mice are resistant to seizures and to neuronal degeneration induced by injection of excitotoxins in the hippocampus (Tsirka et al., 1995). These data suggest an extracellular role for tPA in mediating neuronal degeneration. In an attempt to define the role of tPA in neuronal tissues, we examined the expression of this protease in PC12 cells.

PC12 cells are a clonal neuronal cell line derived from a transplantable rat pheochromocytoma (Greene and Tischler, 1976). As observed previously by Leprince et al. (1991) and Pittman and DiBenedetto (1995), we find that PC12 cells express tPA activity at high levels. However, the enzyme is preferentially retained intracellularly; tPA activity is not detectable in the conditioned medium. Chemical depolarization of the plasma membrane induces the release of tPA in the medium, and this increase is not accompanied by increase in tPA mRNA levels, nor is it prevented by inhibitors of protein synthesis. This membrane depolarization-induced tPA secretion is dependent on $\mathrm{Ca}^{2+}$ in-

Received Oct. 10, 1995; revised Dec. 1, 1995; accepted Jan. 11, 1996.

This work was supported by a fellowship from the University of Florence to A.G. a National Institutes of Health grant to S.S., and IHFSPO to S.E.T. We thank D. Amaral, A. Brignani, M. Frohman, C. Melton, M. Presta, A. Rogove, J. Trimmer, A. Verrotti, J. Wells, and all the members of the Strickland lab for thoughtful discussions and critical reading of this manuscript.

Correspondence should be addressed to Stella E. Tsirka, Department of Pharmacology, BST, T8, Room 125, SUNY at Stony Brook, Stony Brook, NY 11794-8651. Copyright 1996 Society for Neuroscience $0270-6474 / 96 / 162220-06 \$ 05.00 / 0$ flux. Depolarization also affects the release of tPA in vivo, because tPA activity increases in the mouse hippocampus in response to local delivery of $\mathrm{KCl}$. These data demonstrate a novel mechanism by which tPA activity is increased in neural tissue. Given a role for tPA in neuronal plasticity, secretion may be one of the mechanisms by which tPA mediates neuronal remodeling and/or degeneration.

\section{MATERIALS AND METHODS}

Cell culture and conditioning. PC12 cells (a gift from Dr. J. Trimmer, Department of Biochemistry, SUNY, Stony Brook, NY) were grown in DMEM (BioWhittaker, Walkersville, MD) supplemented with $5 \%$ fetal bovine serum and $10 \%$ horse serum (both from JRH Biologicals, Lenexa, $\mathrm{KS}$ ) in the presence of $10 \% \mathrm{CO}_{2}$. For zymography assay (tPA activity assay), cells were split 1:2. After $2 \mathrm{~d}$ the cells were conditioned in medium containing $1 \%$ serum to which the desired drugs were added at the required concentration (see legends to figures). Nifedipine and verapamil were purchased from Sigma (St. Louis, MO).

Preparation of cell extracts for zymography assays. After conditioning, the culture mediun was collected and briefly centrifuged to remove cellular debris. When necessary, the conditioned medium was concentrated by ultrafiltration through Centricon 10 (Amicon, Beverly, MA). Cell monolayers were washed once with $\mathrm{PBS}$, and the cells were lysed by incubation for $1 \mathrm{hr}$ at room temperature with $0.2 \mathrm{ml}$ of $60 \mathrm{~mm}$ Tris- $\mathrm{HCl}, \mathrm{pH} 8.5$, and $0.05 \%$ Triton X-100. Protein concentrations were quantitated using the BCA protein assay (Pierce, Rockford, IL).

Plasminogen activator zymographic assay. For zymographic analysis (Carroll et al., 1993), samples were separated by 10\% SDS-PAGE; after clectrophoresis, the gel was placed in $2.5 \%$ Triton X-100 for $20 \mathrm{~min}$, followed by two washes of 15 min each in water. The gel was then overlaid on substrate matrix containing $50 \mu \mathrm{g} / \mathrm{ml}$ human plasminogen, $2.5 \%$ Carnation nonfat dry milk, $1 \%$ low melting point agarose (FMC Bioproducts, Rockland, ME), and $0.1 \%$ sodium azide. The gel was incubated at $37^{\circ} \mathrm{C}$ for $24-48$ hr in a humidified chamber and ploolographed under dark-field illumination.

Plasminogen activator amidolytic assay. The amidolytic assay was performed as described by Richards et al. (1993).

Total RNA isolation. Total RNA was isolated (Gualandris and Presta, 1995 ) as follows. PC12 cells were plated at subconfluence and transferred to medium with $1 \%$ serum in the presence or absence of $60 \mathrm{~mm} \mathrm{KCl}$ or $50 \mathrm{~mm}$ TEA-Cl. After $3 \mathrm{hr}$ of incubation, the cells were collected in PBS 
by trituration and lysed in $1 \mathrm{ml}$ of $4.2 \mathrm{M}$ guanidine-thiocyanate, $0.5 \%$ sarkosyl, $25 \mathrm{~mm}$ Tris- $\mathrm{HCl}, \mathrm{pH} 8$, and $1 \%$ SDS. After TE $(10 \mathrm{~mm}$ Tris- $\mathrm{HCl}, \mathrm{pH} 7.5,1 \mathrm{~mm}$ EDTA)-saturated phenol-chloroform extraction, nucleic acids were precipitated in 1 vol of ice-cold isopropanol and collected by centrifugation at $8000 \mathrm{rpm}$ for $30 \mathrm{~min}$ at $4^{\circ} \mathrm{C}$. The nucleic acid pellet was resuspended in $200 \mu \mathrm{l}$ of $1 \mathrm{~mm}$ EDTA, $10 \mathrm{~mm}$

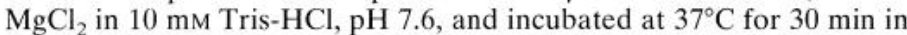
the presence of $25 \mathrm{U}$ of RNase-free RQ1 DNase (Promega, Madison, WI). Total RNA was purified by two extractions with phenolchloroform and precipitated in cold isopropanol. The RNA pellet was resuspended in diethylpyrocarbonate-treated $\mathrm{dH}_{2} \mathrm{O}$, and the nucleic acid concentration was evaluated at $260 \mathrm{~nm}$.

Northern analysis. A full-length tPA riboprobe was obtained from pTAM2.5b plasmid, made available to us by Dr. W. G. Richards (SUNY, Stony Brook, NY). Full-length mouse tPA cDNA $\left[\sim 87\right.$ bp of $5^{\prime}-$ untranslated region (-UTR), the coding region, and 746 bp of $3^{\prime}$-UTR; Rickles et al., 1988], flanked by EcoRI linkers, was subcloned into EcoRI-cut pKS vector (Stratagene, La Jolla, CA). The plasmid was linearized with HindIII and transcribed with T7 RNA polymerase (Epicenter Technologies, Madison, WI) in the presence of $\left[{ }^{32} \mathrm{P}\right]$ uridine triphosphate (DuPont NEN, Boston, MA). The same procedure was used to generate antisense 18S RNA from pT7 18S RNA clone (Ambion, Austin, TX).

Total cellular RNA $(20 \mu \mathrm{g})$ was separated on a $1 \%$ formaldehyde gel and transferred to a nylon filter (Sambrook et al., 1989). Filter hybridization was performed at $65^{\circ} \mathrm{C}$ for $12-20 \mathrm{hr}$ in $10 \mathrm{ml}$ of $1 \%$ bovine serum albumin, $0.2 \mathrm{M} \mathrm{Na}_{2} \mathrm{HPO}_{4}, 1 \mathrm{~mm}$ EDTA, $7 \%$ SDS, and $20 \%$ formamide containing the riboprobe at $5 \times 10^{6} \mathrm{cpm} / \mathrm{ml}$. After hybridization, the filter was washed three times at $65^{\circ} \mathrm{C}, 30 \mathrm{~min}$ for each wash, with $150 \mathrm{~mm}$ $\mathrm{Na}_{2} \mathrm{HPO}_{4}$ and $1 \%$ SDS; the filter was exposed to Kodak XAR-5 film (Rochester, NY) at $-80^{\circ} \mathrm{C}$.

Surgical procedure for pump implantation. Adult male mice $(\mathrm{C} 57 \mathrm{Bl} / 6 \mathrm{~J}$ from Jackson Laboratories, Bar Harbor, ME), weighing $\sim 25 \mathrm{gm}$, were injected intraperitoneally with atropine $(0.6 \mathrm{mg} / \mathrm{kg}$ body weight), anesthetized with $2.5 \%$ avertin $(0.1 \mathrm{ml} / 5 \mathrm{gm}$ body weight $)$ and placed in a stereotaxic apparatus. A hole was drilled in the skull according to the following coordinates: bregma $-2.5 \mathrm{~mm}$, medial lateral $1.7 \mathrm{~mm}$, and dorsoventral $1.6 \mathrm{~mm}$ (Andersson et al., 1991). The brain infusion cannula, connected to a $100 \mu \mathrm{l}$ osmotic pump, was inserted into the hole and secured to the skull with dental cement. The attached miniosmotic pump was placed in the subcutaneous tissue on the back of the animal. The skin was sutured over the cannula-pump assembly. Both osmotic pump and brain infusion assembly were purchased from Alzet (Palo Alto, CA). The animals were perfused for $10 \mathrm{hr}$ at the rate of $0.5 \mu \mathrm{l} / \mathrm{hr}$ with artificial CSF $(\mathrm{aCSF}$ ) with or without $60 \mathrm{~mm} \mathrm{KCl}$. Then mice were killed and the brains were removed, frozen in acetone in a dry ice/ethanol bath, and stored at $-70^{\circ} \mathrm{C}$.

Histological zymography. Histological zymography was performed on brain cryostat tissue sections (Sappino et al., 1993; Tsirka et al., 1995) with or without $1 \mathrm{~mm}$ amiloride.

\section{RESULTS}

\section{PA activity is intracellular in PC12 cells}

The expression of plasminogen activators (PA) has been analyzed in PC12 cells (Greene and Tischler, 1976). Most of this activity is cell-associated, and all was attributable to tissue plasminogen activator (tPA), with no urokinase PA (uPA) activity detectable (Leprince et al., 1991; Pittman and DiBenedetto, 1995). When we evaluated by zymography the expression of PAs in PC12 extracts, a 70-75 kDa caseinolytic band, comigrating with the recombinant murine tPA, was detected in the cellular lysate. No band could be detected in the conditioned medium of the cells (Fig. 1). To address the possibility that the PA activity was too dilute to be detected, we concentrated the medium and, again, no activity was observed (medium 10×, Fig. 1). No cell-associated or released $45-50 \mathrm{kDa}$ band, comigrating with the murine recombinant uPA, was detected.

The cell-associated tPA in PC12 cells is primarily intracellular, because the activity was protected from the action of extracellular proteases such as pronase or trypsin (data not shown). This result eliminates the possibility that tPA is secreted and bound extracel-

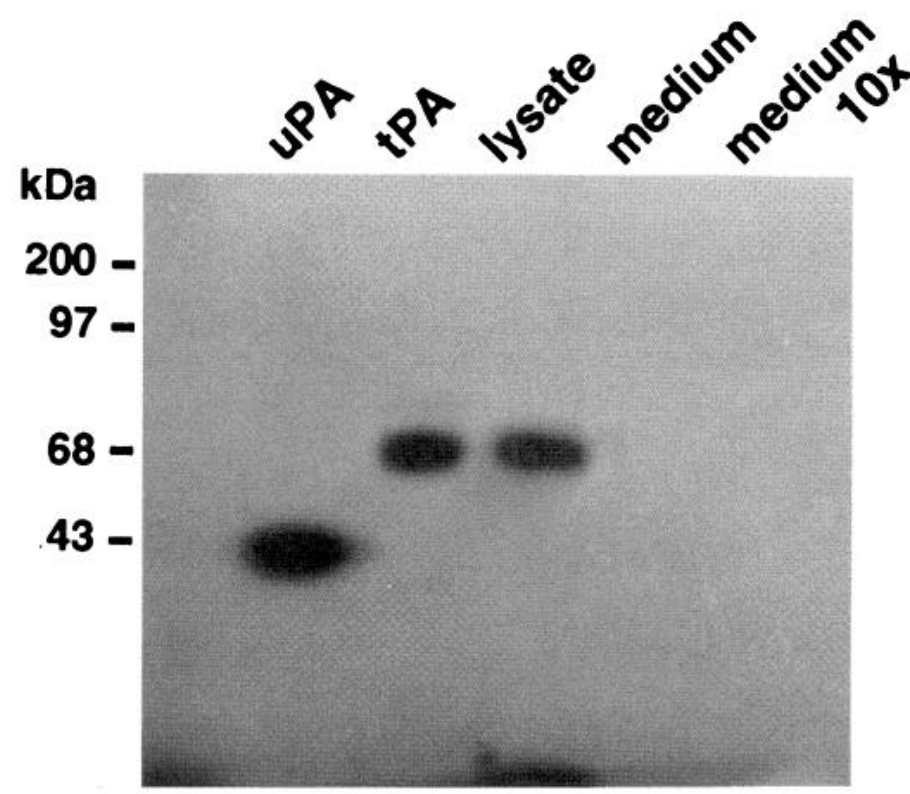

Figure 1. Zymographic analysis of plasminogen activator activity in $\mathrm{PC} 12$ cells. Cell lysate $(100 \mu \mathrm{g}$; lysate $)$ and a $50 \mu \mathrm{l}$ fraction of conditioned medium (medium) were collected from a subconfluent dish of PC12 cells, as described in Materials and Methods, and assayed for caseinolytic activity. In the right lane, the remaining conditioned medium was concentrated, as described, and assayed (medium 10×). Lane uPA, The PA activity developed by $2 \mathrm{ng}$ of recombinant mouse uPA. Lane tPA, The PA activity developed by $2 \mathrm{ng}$ of recombinant mouse tPA. Protein molecular weight standards are indicated to the left.

lularly to a putative receptor as in mouse oocytes (Carroll et al., 1993).

\section{Membrane-depolarizing drugs induce tPA secretion in PC12 cells}

tPA is expressed in the murine brain (Rickles and Strickland, 1988; Sappino et al., 1993) and is transcriptionally induced as an immediate-early gene when neuronal activity is stimulated (Qian et al., 1993; Carroll et al., 1994). The activity of tPA is correlated with neurite outgrowth, regeneration, and migration (Krystosek and Seeds 1981a,b; Sallés et al., 1990). In addition, tPA mediates neuronal degeneration when kainic acid and other glutamate receptor agonists are introduced in the hippocampus (Tsirka et al., 1995). It is known that intracerebral administration of kainic acid induces a rapid depolarization of the neuronal membrane (Lipton and Rosenberg, 1994). On this basis, the response of tPA to chemically induced membrane depolarization was analyzed in PC12 cells. This treatment can induce secretory activity of neuronal cells (Gonzalez-Garcia et al., 1993; Stuenkel and Nordmann, 1993); it also mimics the transmission of electrical impulses and can activate the expression of immediate-early genes both in vivo (Herdegen et al., 1993; Herrera et al., 1993) and in vitro (Yoon and Lau, 1994).

Two depolarizing agents were used: $\mathrm{KCl}$ and tetraethylammonium chloride (TEA-Cl). Both agents were able to induce tPA release within $30 \mathrm{~min}$ (Fig. 2A,B, bottom panels). A time-dependent decrease of tPA activity was detectable in the corresponding cell lysates (Fig. $2 A, B$, top panels), suggesting that membrane depolarization induces the secretion of tPA previously synthesized and stored intracellularly.

This suggestion is strengthened by $\mathrm{KCl}$ and TEA-Cl doseresponse experiments: the tPA cell-associated versus secreted activities show opposite trends when PC12 cells are incubated with increasing amounts of $\mathrm{KCl}$ (Fig. $2 \mathrm{C}$ ) or TEA-Cl (Fig. 2D; 
A
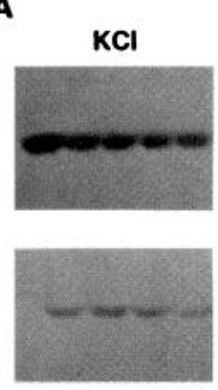

$\begin{array}{lllll}0 & 0.5 & 1 & 3 & 5\end{array}$

C
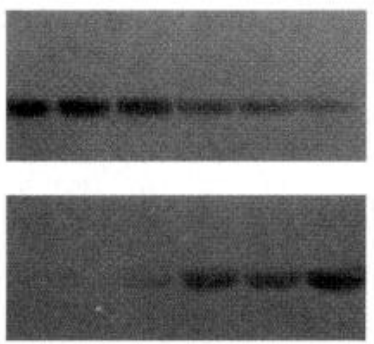

$\begin{array}{llllll}0 & 10 & 20 & 40 & 60 & 80\end{array}$
B

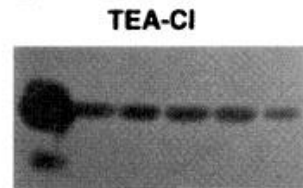

Iysates

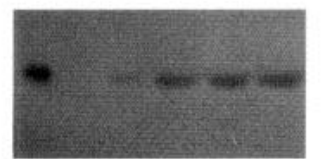

$\begin{array}{llllll}\text { IPA } & 0 & 0.5 & 1 & 3 & 5\end{array}$

D
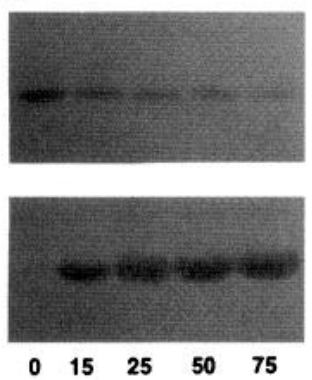

Dose, $\mathrm{mM}$

E

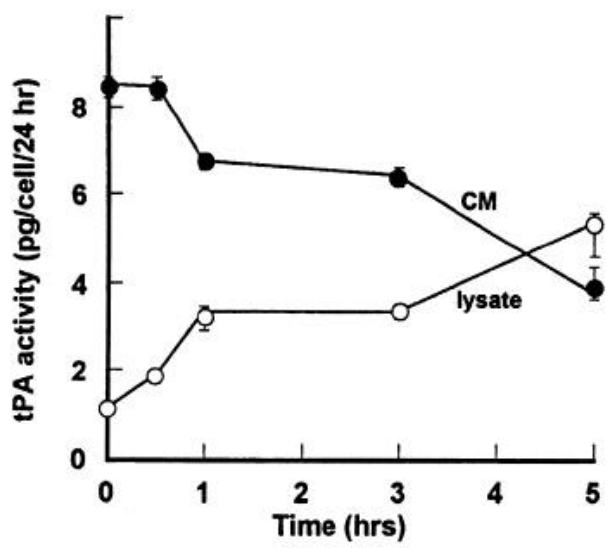

Figure 2. Time course and dose response of tPA activity to membranedepolarizing agents. $A, B$, Zymographic analysis of tPA activity in response to increasing time of incubation of $\mathrm{PC} 12$ cells with $60 \mathrm{~mm} \mathrm{KCl}(A)$, or with $50 \mathrm{~mm}$ TEA-Cl $(B)$. For each experimental point, the PA activity of cellular lysates (100 $\mu \mathrm{g}$, top panels $)$ and of conditioned media, normalized for protein content (bottom panels), is shown. $C, D, \mathrm{tPA}$ activity in cell lysates $(100 \mu \mathrm{g}$, top panels $)$ and in conditioned media $(\sim 50 \mu \mathrm{l}$ normalized for protein, bottom panels) of PC12 cells incubated for $1 \mathrm{hr}$ with increasing amounts of $\mathrm{KCl}(C)$ or TEA-Cl $(D)$. In each panel, lane 0 indicates the released or the cell-associated PA activity detected in normal conditions of cell growth (medium supplemented with $1 \%$ serum). E, Quantitation of tPA activity by amidolytic assay of samples in $A$. The activity measurements were done in triplicate. Open circles, tPA activity in cell lysates; closed circles, tPA activity in conditioned media $(C M)$ as in $A$.

compare the top panels with the bottom panels where increase of activity in the culture medium parallels the decrease in activity of the intracellular enzyme).

When the PA activity was quantitated, released tPA activity increased over time from 1.1 to $5 \mathrm{pg} / \mathrm{cell} / 24 \mathrm{hr}$ in $\mathrm{KCl}$-treated conditioned media (Fig. 2E). Similar data were obtained for TEA-Cl-treated PC12 cells (data not shown).
To examine whether the $\mathrm{KCl}$ or TEA-Cl effect on tPA was specific or caused by an increase in osmolarity, cells were incubated with $60 \mathrm{~mm} \mathrm{NaCl}$; no effect on the expression of tPA was observed (data not shown), indicating that the secretion of tPA is attributable to the membrane-depolarizing effect of $\mathrm{KCl}$ and TEA-Cl. To evaluate whether the release of tPA is a physiological phenomenon rather than a pathological one (due to cytotoxicity of the depolarizing agents), we used two different approaches.

(1) The expression of Fos protein in cellular lysates or conditioned media from PC12 cells was examined. Extracts and conditioned media from cells that had or had not been treated with 60 $\mathrm{mm} \mathrm{KCl}$ or $50 \mathrm{~mm}$ TEA-Cl were subjected to Western blot analysis using a polyclonal anti-Fos antibody (Santa Cruz Biotechnology, Santa Cruz, CA). In all cases, Fos was immunodetected only in cell lysates and not in conditioned media (data not shown).

(2) The activity of cytosolic lactate dehydrogenase (LDH) was measured in conditioned media from untreated cells $(13 \mathrm{U} / 1)$ or in media from cells treated with $60 \mathrm{~mm} \mathrm{KCl}(11 \mathrm{U} / \mathrm{l})$ or $50 \mathrm{~mm}$ TEA-Cl (13 U/1). These data were obtained from media from four different experiments. No difference was observed in extracellular LDH activity after treatment of PC12 cells with the depolarizing agents.

Both the Fos expression and the LDH activity data demonstrate that the effect of depolarizing compounds on tPA secretion is specific, and not attributable to leakage of intracellular material into the cell media because of $\mathrm{PC} 12$ cell death.

As observed previously by Leprince et al. (1991), we also found that tPA expression in PC12 cells was not correlated with the stage of cellular differentiation: the pattern of tPA expression did not change when PC12 cells differentiated in response to $50 \mathrm{ng} / \mathrm{ml}$ nerve growth factor added to the culture medium. $\mathrm{KCl}$ induced release of tPA in differentiated as well as in undifferentiated cells, showing that the state of differentiation does not alter the $\mathrm{KCl}$ mediated tPA secretion (data not shown).

\section{Membrane depolarization induces tPA release in PC12 cells by acting through a secretory pathway without affecting tPA gene expression}

In PC12 cells, $\mathrm{KCl}$-induced membrane depolarization can activate the transcription of nur77 (Yoon and Lau, 1994); $\mathrm{KCl}$ can also increase the expression of several immediate-early genes in vivo (Herdegen et al., 1993; Herrera et al., 1993). Therefore, we examined whether the tPA activity found in conditioned media in response to depolarizing compounds was a consequence of transcriptional activation of the tPA gene.

Northern blot analysis was performed on total RNAs purified from PC12 cells that had been incubated with or without $60 \mathrm{~mm}$ $\mathrm{KCl}$ or $50 \mathrm{~mm}$ TEA-Cl for $1 \mathrm{hr}$. The intensity of the tPA-specific signal was quantitated and normalized relative to that of $18 \mathrm{~S}$ RNA. As shown in Figure 3, the levels of tPA mRNA did not change after the cell membrane was depolarized ( 0.98 for control; 1.08 for $\mathrm{KCl}$-treated cells; 0.91 for TEA-Cl-treated cells), indicating that the increase in secreted tPA activity is not attributable to increased mRNA levels.

A possible effect of $\mathrm{KCl}$ on the translation of tPA mRNA was also investigated. Extracts from cells that had been treated with $\mathrm{KCl}$ in the presence or absence of cycloheximide were analyzed by zymography assay. Figure 4 shows that blocking protein synthesis by cycloheximide did not affect the $\mathrm{KCl}$ induced tPA release (compare lane $\mathrm{KCl}$ with lane $\mathrm{KCl}+\mathrm{CHX}$, bottom panel). In addition, the cell-associated tPA activity decreased in response to incubation with $\mathrm{KCl}$ in the presence of $\mathrm{CHX}$ as well 

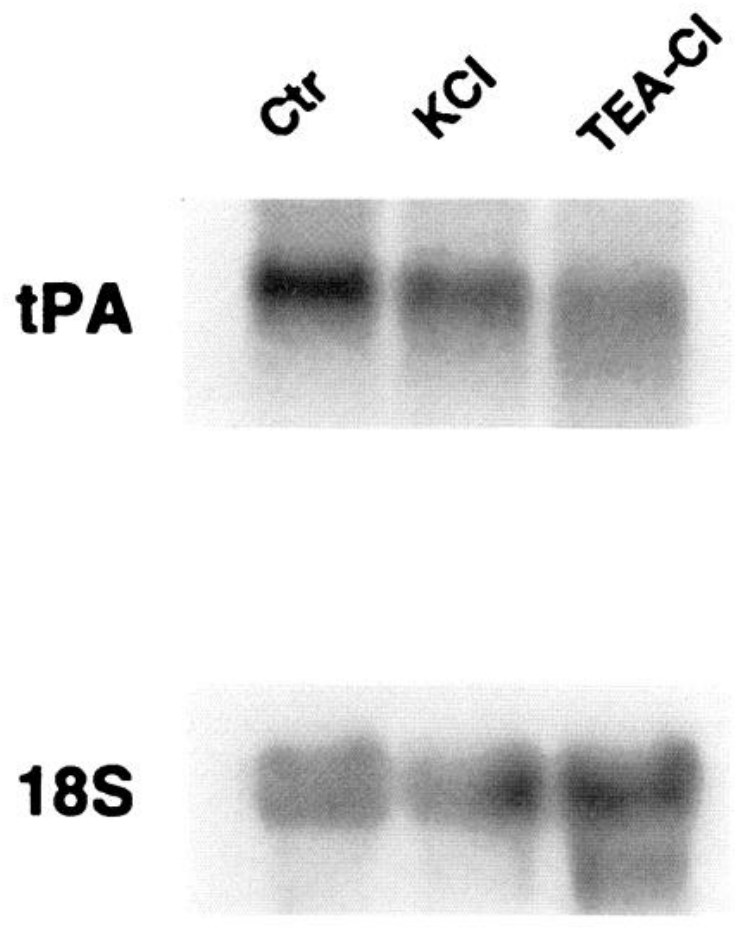

Figure 3. Northern blot analysis of tPA mRNA in response to membrane depolarization. Twenty micrograms of total RNA purified from $\mathrm{PC} 12$ cells treated with $60 \mathrm{~mm} \mathrm{KCl}$ or $50 \mathrm{~mm} \mathrm{TEA-Cl}$ or kept in normal conditions of growth (Ctr) were probed for tPA mRNA (top panel) by Northern blot hybridization. Northern analysis was repeated three times with different RNA preparations, and the hybridization signals were quantitated with a scanning densitometer. 18S RNA (bottom panel) was used to normalize the amount of hybridized tPA mRNA.

as in its absence (top panel). Under the same experimental conditions, cycloheximide reduced $\left[{ }^{35} \mathrm{~S}\right]$ methionine incorporation and, by inference, protein synthesis by $\sim 91 \%$ (data not shown).

These findings demonstrate that in PC12 cells membrane depolarization induces release of presynthesized tPA.

\section{Membrane depolarization-induced tPA secretion is $\mathrm{Ca}^{2+}$ influx-dependent}

In PC12 cells, the release of catecholamines, induced by membrane depolarization, requires $\mathrm{Ca}^{2+}$ influx through calcium channels located in the plasma membrane (Ashery et al., 1993). Similarly, influx of $\mathrm{Ca}^{2+}$ is essential for the membrane depolarization-induced release of insulin by rat islets cells and of dopamine by rabbit carotid cells (Kelley et al., 1994; Urena et al., 1994). To investigate whether $\mathrm{Ca}^{2+}$ is required for the release of $\mathrm{TPA}$ after membrane depolarization, $\mathrm{PC} 12$ cells were incubated with $\mathrm{KCl}$ or TEA-Cl in the presence or absence of the $\mathrm{Ca}^{2+}$ channel blockers nifedipine or verapamil. As shown in Figure 5, addition of either $10 \mu \mathrm{M}$ nifedipine or $20 \mu \mathrm{M}$ verapamil results in inhibition of $\mathrm{KCl}$-induced release of tPA activity (Fig. 5A,B, bottom panels). Neither nifedipine nor verapamil affects the cell-associated tPA activity when added alone (Fig. 5A,B, compare Nif and Ver lanes with untreated lane, top panels). The capacity of TEA-Cl to induce tPA secretion was also inhibited by nifedipine or verapamil (Fig. $5 C$, lanes $T E A-C l+N i f$ and $T E A-C l+V e r$ vs lane $T E A-C l)$. These results demonstrate the requirement for influx of calcium for the membrane depolarization-mediated tPA secretion.

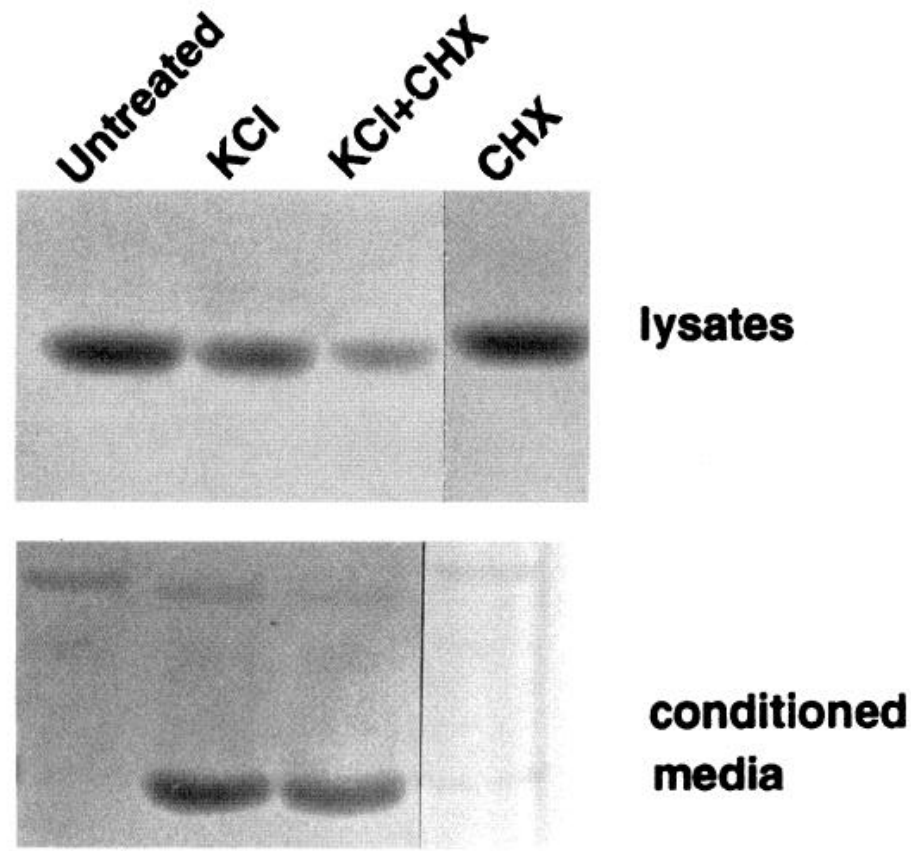

Figure 4. Effect of protein synthesis inhibition on membrane depolarization-induced tPA release. $\mathrm{PC} 12$ cells were pretreated for $1.5 \mathrm{hr}$ with $1 \%$ medium containing $3 \mu \mathrm{g} / \mathrm{ml}$ cycloheximide; the next $5 \mathrm{hr}$ of incubation were performed in the presence or in the absence of $60 \mathrm{~mm}$ $\mathrm{KCl}$ added to cell culture medium. At the end of the treatment, tPA activity was analyzed in the conditioned media and cellular lysates by zymography assay. Left two lanes, tPA activity from $100 \mu \mathrm{g}$ of cellular lysates (top panel) and from $50 \mu \mathrm{l}$ of conditioned media (bottom panel) collected from PC12 cells grown for $5 \mathrm{hr}$ in $1 \%$ serum (Untreated) or in $1 \%$ serum containing $60 \mathrm{~mm} \mathrm{KCl}$. Right two lanes, tPA activity from $100 \mu \mathrm{g}$ of cell lysates (top panel) and from $50 \mu \mathrm{l}$ of conditioned media (bottom panel) collected from $\mathrm{PC} 12$ cells treated with cycloheximide and $\mathrm{KCl}$ $(\mathrm{KCl}+\mathrm{CHX})$ or with only cycloheximide $(\mathrm{CHX})$.

\section{Analysis of tPA activity after in vivo administration of $\mathbf{K C l}$}

Based on the data obtained with the cell culture, the effects of in vivo $\mathrm{KCl}$ administration were analyzed in the mouse brain. $\mathrm{KCl}$ was delivered to the CNS of adult mice in a time-release mode by the implantation of a brain infusion system (see Material and Methods). After $10 \mathrm{hr}$ of infusion, tPA activity was analyzed by histological zymography performed on brain sections of three control animals (Fig. 6, control) and three animals treated with $\mathrm{KCl}$ (Fig. 6, $+\mathrm{KCl}$ ). tPA activity around the $\mathrm{CA} 2-\mathrm{CA} 3$ and dentate gyrus (DG) regions of the hippocampal formation was increased in $\mathrm{KCl}$-infused brain sections compared with control brain sections infused with buffer alone (see arrows in Fig. 6). Identical results were obtained when $1 \mathrm{~mm}$ amiloride, a selective uPA inhibitor (Vassalli and Belin, 1987), was included in the overlay matrix, confirming that the observed caseinolytic activity is attributable to tPA and not to uPA (Vassalli et al., 1991). When plasminogen was omitted from the overlay matrix, no caseinolytic activity was detected. Because histological zymography reveals the localization of extracellular PA activity (Sappino et al., 1993), and because it is known that membrane-depolarizing compounds increase the secretory activity in vivo (Paulsen et al., 1989; Szerb et al., 1991), we postulate that $\mathrm{KCl}$ increases tPA activity along the CA2-CA3 and DG regions of the hippocampus by inducing tPA secretion. These results suggest also that physiological or pathological situations leading to membrane depolarization could be associated with a rise in tPA secretion in the brain. 

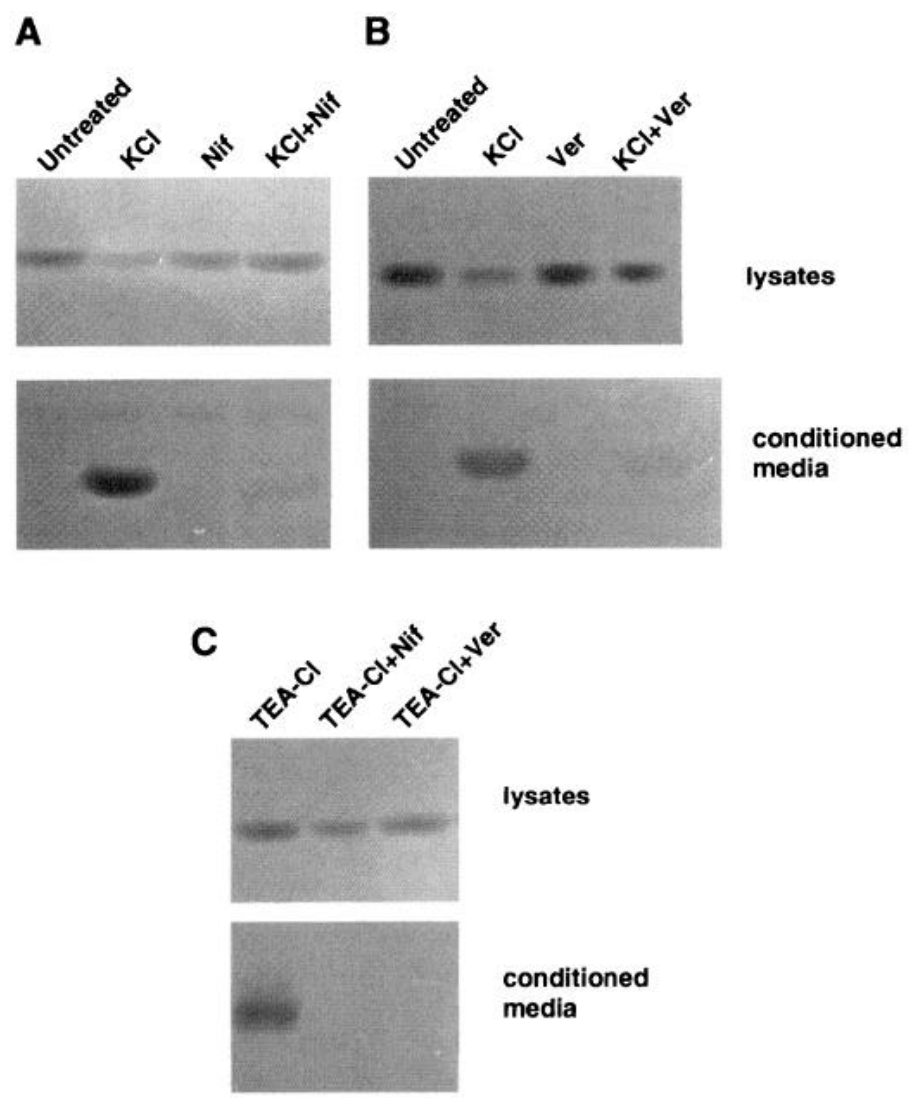

Figure 5. Effect of $\mathrm{Ca}^{2+}$ channel blockers on membrane depolarizationinduced tPA release. PC12 cells were grown as described in Figure 1. Concomitantly with transferring the cells to $1 \%$ serum, $60 \mathrm{mM} \mathrm{KCl}, 10 \mu \mathrm{M}$ nifedipine, $60 \mathrm{mM} \mathrm{KCl}$ plus $10 \mu \mathrm{M}$ nifedipine, $20 \mu \mathrm{M}$ verapamil, and $60 \mathrm{~mm}$ $\mathrm{KCl}$ plus $20 \mu \mathrm{M}$ verapamil were added and the cells were incubated further for $30 \mathrm{~min}$ at $37^{\circ} \mathrm{C}$. tPA activity was then analyzed on cell lysates or in the media by zymographic assays. $A$, Zymography performed on cellular lysates $(100 \mu \mathrm{g}$, top panel $)$ and on the corresponding conditioned media $(50 \mu \mathrm{l}$, bottom panel) with $60 \mathrm{~mm} \mathrm{KCl}, 10 \mu \mathrm{M}$ nifedipine (Nif), and $60 \mathrm{~mm}$ $\mathrm{KCl}$ plus $10 \mu \mathrm{M}$ nifedipine $(\mathrm{KCl}+\mathrm{Nif})$. B, Zymography assay performed on cellular lysates (top panel) and on the corresponding conditioned media

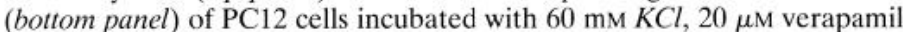
(Ver), and $60 \mathrm{~mm} \mathrm{KCl}$ plus $20 \mu \mathrm{M}$ verapamil $(\mathrm{KCl}+\mathrm{Ver}) . \mathrm{C}$, Zymography assay performed on cellular lysates and on the corresponding conditioned media after incubating PC12 cells with $50 \mathrm{~mm} T E A-C l$ or $50 \mathrm{~mm}$ TEA-Cl in the presence of $10 \mu \mathrm{M}$ nifedipine $(T E A-C l+N i f)$ or $20 \mu \mathrm{M}$ verapamil (TEA-Cl+Ver).

\section{DISCUSSION}

There is increasing evidence that protease and protease inhibitors play a critical role in the CNS. The serine protease tPA has been identified as an immediate-early response gene in the rat hippocampus in response to neuronal stimuli (Qian et al., 1993). In addition, mice deficient for tPA display resistance to pharmacologically provoked seizures and excitotoxin-induced neuronal degeneration in the hippocampus (Tsirka et al., 1995). These results indicate that tPA has an important influence in neuronal events and imply that its activity must be carefully regulated. In this paper, we show that membrane depolarization results in the secretion of preformed tPA via a $\mathrm{Ca}^{2+}$-dependent pathway. Our data suggest that secretion represents a regulatory step for the activity of tPA and may contribute to the mechanism by which tPA mediates neuronal plasticity in the brain.

The amount of tPA in extracellular fluid can be regulated by various mechanisms. One such mechanism is the increase in tPA mRNA that occurs in the hippocampus after treatments that

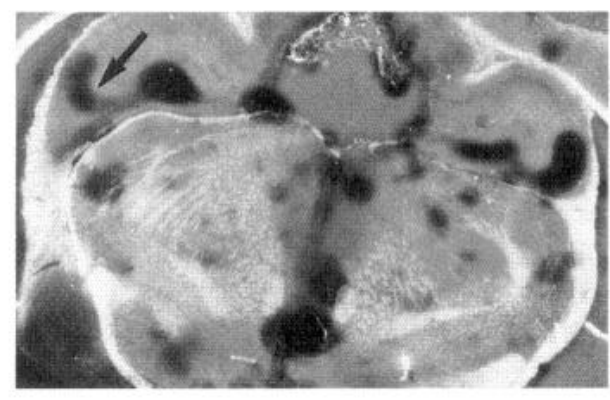

Control

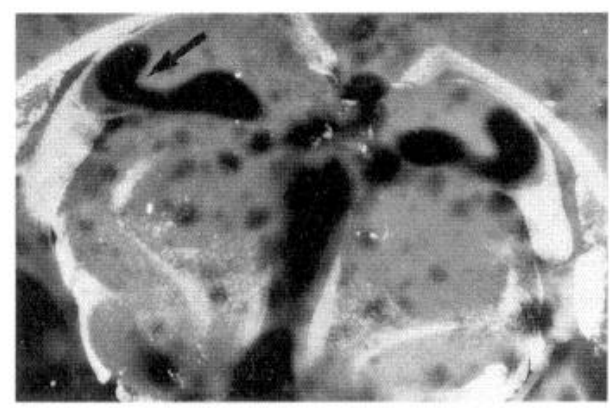

$+\mathrm{KCl}$

Figure 6. Localization of tPA activity in the murine brain in response to $\mathrm{KCl}$ infusion. $\mathrm{C} 57 \mathrm{Bl} / 6 \mathrm{~J}$ mice were perfused for $12 \mathrm{hr}$ with aCSF (Control) or with aCSF supplemented with $60 \mathrm{~mm} \mathrm{KCl}(+\mathrm{KCl})$ by implanting a micro-osmotic pump, as described in Materials and Methods. Consecutive coronal brain cryostat sections $(12 \mu \mathrm{m})$ were overlaid with a milk-agarose substrate matrix containing $50 \mu \mathrm{g} / \mathrm{ml}$ purified human plasminogen. Photographs were taken under dark-field illumination after $2 \mathrm{hr}$ of incubation at $37^{\circ} \mathrm{C}$. PA activity was not detected along the injection track, indicating that mechanical injury does not induce release of tPA.

induce neuronal remodeling (Qian et al., 1993; Carroll et al., 1994). A second possibility is translational control of tPA mRNA (Huarte et al., 1985), although this form of modulation has not been observed in the CNS. Our results add the control of secretion to the list of possible regulatory pathways. There could be several advantages to the regulation of enzyme levels via secretory control. (1) If a situation (e.g., presence of excess excitatory amino acid) required increased extracellular tPA, enhancing secretion would allow a maximally rapid response. (2) It is possible that increased tPA activity might be required only in specific cellular regions, e.g., at individual synapses. Control of secretion might allow this increase to occur only in areas that exhibit neuronal stimulation. In this respect, there is evidence that in adrenal chromaffin cells tPA is stored in catecholamine storage vesicles and is released along with catecholamines after treatment with secretagogues (R. Parmer and L. Miles, personal communication).

The excessive activation of glutamate receptors via different glutamate agonists, termed excitotoxicity, is the primary source of degeneration in the CNS (Schreiber and Baudry, 1995). Glutamate agonists act by depolarizing the cell membrane which, in turn, increases the concentration of intracellular calcium (Munsch et al., 1994). This rise in the concentration of $\mathrm{Ca}^{2+}$ leads to delayed forms of neuronal degeneration and death by triggering lethal biochemical pathways that involve degradative enzymes, such as proteases and endonucleases (Schreiber and Baudry, 1995). In addition, in PC12 cells, as well as in other non-neuronal cell lines and in hypothalamic slices, depolarization and the rise in the concentration of intracellular $\mathrm{Ca}^{2+}$ lead to the secretion of hormones and neurotransmitters previously associated with intra- 
cellular vesicles (Ashery et al., 1993; Stuenkel et al., 1993; Kelley et al., 1994; Troger et al., 1994).

The increased tPA secretion rate after depolarization suggests a connection between neuronal degeneration and the regulation of tPA secretion. This type of regulation conld occur in vivo, because after $\mathrm{KCl}$ perfusion into the hippocampus an increase in tPA activity is observed. Because of its proteolytic activity, the released tPA could potentiate the neurodegenerative pathway and the morphological changes that follow excessive neuronal stimulation.

The mouse mutant weaver exhibits ataxia attributable to virtually complete granule neuronal death in the cerebellum. It has been shown that there is 10 -fold more tPA present in the cerebellum of these mice than in wild-type mice (Murtomäki et al., 1995). Recently, the weaver gene was identified (Patil et al., 1995) and shown to encode an inward rectifying potassium channel (GIRK2). It is intriguing to speculate that in weaver mice this mutated potassium channel leads to misregulation of potassium concentration and chronic depolarization of the membranes of granule cells, resulting in increased tPA secretion and eventual neuronal degeneration.

Further studies in vivo are in progress to investigate whether tPA secretion and its regulation are involved in the phenomena that characterize neuronal injury. The integrative regulation of extracellular tPA will undoubtedly be complex. In addition to the direct effects on the amount of tPA proteolytic activity discussed above, the manifested tPA activity could also be profoundly influenced by extracellular protease inhibitors. The results reported here identify a secretory control that may contribute to both the rapidity and spatial expression of tPA activity and, therefore, might function in neuronal remodeling and degeneration.

\section{REFERENCES}

Andersson PB, Perry VH, Gordon S (1991) The kinetics and morphological characteristics of the macrophage-microglial response to kainic acid-induced neuronal degeneration. Neuroscience 42:201-214.

Ashery V, Weiss C, Sela D, Spira ME, Atlas D (1993) Membrane depolarization combined with release of calcium from internal stores does not trigger secretion from PC12 cells. Receptors Channels 1:217-220.

Carroll PM, Richards WG, Darrow AL, Wells JM, Strickland S (1993) Preimplantation mouse embryos express a cell surface receptor for tissue plasminogen activator. Development 119:191-198.

Carroll PM, Tsirka SE, Richards WG, Frohman MA, Strickland S (1994) The mouse tissue plasminugen aclivalur gene 5' llanking region directs appropriate expression in development and a seizure-enhanced response in CNS. Development 120:3173-3183.

Gonzalez-Garcia C, Lena V, Keiser HR, Rojas E (1993) Catecholamine secretion induced by tetraethylammonium from cultured bovine adrenal chromaffin cells. Biochim Biophys Acta 1177:99-105.

Greene LA, Tischler AS (1976) Establishment of noradrencrgic clonal line of rat adrenal pheochromocytoma cells which respond to nerve growth factor. Proc Natl Acad Sci IJSA 73:2424-2428.

Gualandris A, Presta M (1995) Transcriptional and post-transcriptional regulation of urokinase-type plasminogen activator expression in endothelial cells by basic fibroblast growth factor. J Cell Physiol 162:400 409.

Herrera DG, Maysinger D, Goiny M (1993) Induction of c-FOS immunoreactivity in the hippocampus following potassium stimulation. Neuroscience 52:237-244.

Herdegen T, Sandkühler P, Gass P, Kieshing M, Bravo R, Zimmermann M (1993) Jun, Fos, Crox and Creb transcription factor proteins in the rat cortex: basal expression and induction by spreading depression and cpileptic seizure. J Comp Neurol 333:271-288.

Huarte J, Belin D, Vassalli JD (1985) Plasminogen activator in mouse and rat oocytes: induction during meiotic maturation. Cell 43:551-558.

Kelley GG, Zawalich KC, Zawalich WS (1994) Calcium and mitochondrial signals interact to stimulate phosphoinositide hydrolysis and insulin secretion in rat islet. Endocrinology 134:1648-1654.
Krystosek A, Seeds N (1981a) Plasminogen activator secretion by granule neurons in cultures of developing cerebellum. Proc Natl Acad Sci USA 78:7810-7814.

Krystosek A, Secds N (1981b) Plasminogen activator release at neuronal growth cone. Science 213:1532-1534.

Leprince P, Rogister B, Delrée P, Rigo JM, André B, Moonen G (1991) Modulation of proteolytic activity during neuritogenesis in PC12 nerve cells: differential control of plasminogen activator and plasminogen activator inhibitor activities by nerve growth factor and dibutyryl-cyclic AMP. J Neurochem 57:665-674.

Lipton SA, Rosenberg PA (1994) Excitatory amino acids as a final common pathway for neurologic disorders. N Engl J Med 330:613-622.

Munsch T, Nett W, Deitmer JW (1994) Fura-2 signals evoked by kainate in leech glial cells in the presence of different divalent cations. Glia $11: 345-353$

Murtomäki S, Ekkhart T, Wright JM, Saksela O, Liesi P (1995) Increased proteolytic activity of the granule neurons may contribute to neuronal death in the weaver mouse ccrebellum. Dev Biol 168:635-648.

Patil N, Cox DR, Bhat D, Faham M, Myers RM, Peterson AS (1995) A potassium channel mutation in weaver mice implicates membrane excitability in granule cell differentiation. Nature Genet 11:126-129.

Paulsen RE, Fonnum F (1989) Role of glial cells for the basal and $\mathrm{Ca}^{2+}$ dependent $\mathrm{K}^{+}$-cvoked relcase of transmitter amino acids investigated by microdialysis. J Neurochem 52:1823-1829.

Pittman RN, DiBenedetto AJ (1995) PC12 cells overexpressing tissue plasminogen activator regenerate neurites to a greater extent and migrate faster than control cells in complex extracellular matrix. J Neurochem 64:566-575.

Qian Z, Gilbert M, Colicos M, Kandel E, Kuhl D (1993) Tissue plasminogen activator is induced as an immediatc-carly gene during seizure, kindling and long term potentiation. Nature 361:453-457.

Richards WG, Carroll PM, Kinloch RA, Wassarman PM, Strickland S (1993) Creating maternal effect mutations in transgenic mice: antisense inhibition of an oocyte gene product. Dev Biol 160:543-553.

Rickles RJ, Strickland S (1988) The plasminogen activator in murine tissues. FEBS Lett 229:100-106.

Rickles RJ, Darrow AL, Strickland S (1988) Molecular cloning of complementary DNA to mouse tissue plasminogen activator mRNA and its expression during F9 teratocarcinoma cell differentiation. J Biol Chem 263:1563-1569.

Sallés FJ, Schechter N, Strickland S (1990) A plasminogen activator is induced during goldfish optic nerve regeneration. EMBO J 9:2471-2477.

Sambrook J, Fritsch EF, Maniatis T (1989) Molecular cloning: a laboratory Manual, 2nd Ed. Cold Spring Harbor, NY: Cold Spring Harbor Laboratory.

Sappino AP, Madani R, Huarte J, Belin D, Kiss JZ, Wohlwend A, Vassalli JD (1993) Extracellular proteolysis in the adult murine brain. J Clin Invest 92:679-685.

Schreiber SS, Baudry M (1995) Selective neuronal vulnerability in the hippocampus: a role for gene expression? Trends Neurosci 18:445-451.

Stuenkel EL, Nordmann JJ (1993) Intracellular calcium and vasopressin release of rat isolated neurohypophysial nerve endings. J Physiol (Lond) 468:335-355.

Szerb JC (1991) Glutamate release and spreading depression in the fascia dentata in response to microdialysis with high $\mathrm{K}^{1}$ : role of glia. Brain Res 542:259-265.

Troger J, Kirchmair R, Marksteiner J, Seidl CV, Fischer-Colbrie R, Saria A, Winkler H (1994) Release of secretoneurin and noradrenaline from hypothalamic slices and its differential inhibition by calcium channel blockers. Naunyn Schmiedebergs Arch Pharmacol 349:565-569.

Tsirka SE, Gualandris A, Amaral DG, Strickland S (1995) Excitotoxininduced neuronal degeneration and seizure are mediated by tissue plasminogen activator. Nature 377:340-344.

Urena J, Fernandez-Chacon R, Benot AR, Alvarez de Toledo GA, LopezBarneo J (1994) Hypoxia induces vollage-dependent $\mathrm{Ca}^{2+}$ entry and quantal dopamine secretion in carotid body glomus cells. Proc Natl Acad Sci USA 91:10208-10211.

Vassalli JD, Belin D (1987) Amiloride selectively inhibits the urokinasetype plasminogen activator. FEBS Lett 214:187-191.

Vassalli JD, Sappino AP, Belin D (1991) The plasminogen activator plasmin system. J Clin Invest 88:1067-1072.

Yoon JK, Lau LF (1994) Involvement of JunD in transcriptional activation of the orphan receptor gene nur77 by nerve growth factor and membrane depolarization in PC12 cells. Mol Cell Biol 14:7731-7743. 